\title{
Loyalitas Pelanggan Pada Business-To-Business: Pengaruh Kualitas Pelayanan
}

\author{
Lulu Marjani $^{1^{*}}$ dan Mamun Sutisna ${ }^{2}$ \\ ${ }^{1}$ Administrasi Niaga, Politeknik Negeri Bandung, Indonesia \\ ${ }^{2}$ Administrasi Niaga, Politeknik Negeri Bandung, Indonesia
}

\begin{abstract}
:
Customer loyalty is the key to the success of every company, especially in business to business (B2B) markets where the company has a long-term orientation business. Due to the importance of maintaining the quality of service to create customer loyalty, this research was conducted to determine the effect of service quality on customer loyalty on business to business. This research uses 117 business to business customers as respondents. The results of this study illustrate that service quality has an effect of 54,6\% on customer loyalty.
\end{abstract}

Keywords: business to business, service quality, customer loyalty

\begin{abstract}
Abstrak:
Loyalitas pelanggan adalah kunci keberhasilan setiap perusahaan, terutama dalam pasar bisnis ke bisnis (B2B) di mana perusahaan memiliki bisnis orientasi jangka panjang. Karena pentingnya menjaga kualitas layanan untuk menciptakan loyalitas pelanggan, penelitian ini dilakukan untuk mengetahui pengaruh kualitas layanan terhadap loyalitas pelanggan pada bisnis ke bisnis. Penelitian ini menggunakan 117 pelanggan bisnis ke bisnis sebagai responden. Hasil penelitian ini menggambarkan bahwa kualitas layanan memiliki pengaruh 54,6\% terhadap loyalitas pelanggan.
\end{abstract}

Kata kunci: bisnis ke bisnis, kualitas layanan, loyalitas pelanggan

\section{Pendahuluan}

\subsection{Latar Belakang}

Perkembangan bisnis setiap tahunnya menuntut perusahaan untuk mampu bertahan, khususnya saat ini bisnis harus berorientasi pada pelanggan, di mana perusahaan harus bisa menjadikan pelanggan merupakan prioritas utamanya untuk mencapai kesuksesan bisnis. Oleh karena itu, penting bagi setiap perusahaan agar bisa menyesuaikan diri dengan pekembangan modern. Memberikan pelayanan prima kepada seluruh pelanggan merupakan proses dalam memperoleh kesuksesan bisnis.

Upaya untuk meningkatkan pelayanan prima kepada seluruh pelanggan maka perusahaan harus bisa mendefinisikan di mana target pasar mereka, apakah strategi bisnis yang diterapkan perusahaan adalah business to business (B2B) atau perusahaan yang bergerak pada strategi business to customer (B2C), perbedaan B2B ada pada jumlah pembeli yang cenderung lebih sedikit namun mereka mampu 
membeli suatu produk (barang/jasa) dalam jumlah yang lebih besar, selain itu B2B memiliki karakteristik di mana hubungan pemasok dan pelanggan yang erat.

Business to business dapat dikatakan sebagai bisnis yang akan sangat menguntungkan dalam jangka panjang atau di sebut juga long term orientation. Tujuan bisnis secara umum yaitu memperoleh laba sebesar-besarnya, tujuan ini akan tercapai pada bisnis yang bergerak dalam B2B ketika bisnis mampu memberikan nilai kepada pelanggan dan bisnis mampu memanfaatkan hubungan baik dengan para pelanggan. Kualitas keberhasilan perusahaan salah satunya ditentukan oleh seberapa banyak harapan mereka terpenuhi oleh perusahaan, sehingga pelanggan bisa merasakan kepuasan atas produk barang/jasa yang dibelinya pada perusahaan tersebut. Selain itu, ketika perusahaan bisa memberikan nilai tambah dan kepuasan kepada seluruh pelanggannya maka tujuan perusahaan dalam jangka panjang dapat direalisasikan yaitu, perusahaan yang memiliki pelanggan loyal.

Penelitian dilakukan di toko Niaga Wood yang memiliki target pasar B2B. Toko Niaga Wood merupakan toko yang menjual alat-alat meubel, perkakas dan material meubel di Kota Cimahi sejak tahun 2013. Saat ini perkembangan bisnis yang menjual material meubel bergerak cepat, hal ini terlihat karena hingga sekarang sudah terdapat kompetitor-kompetitor baru yang menjual produk sejenis untuk memenuhi kebutuhan pelanggan, yaitu pelanggan memiliki usaha di bidang industri manufaktur meubel di Kota Cimahi.

Kegiatan menjual dengan menyediakan material dan alat-alat meubel di toko Niaga Wood merupakan upaya perusahaan memenuhi kebutuhan pengerajin meubel di Kota Cimahi dalam mencapai keberhasilan. Namun, setelah diamati tenyata terdapat celah-celah kekurangan pada toko Niaga Wood melalui tanggapan dan keluhan yang disampaikan pelanggan baik secara langsung dan tidak langsung, seperti beberapa pelanggan merasakan adanya pelayanan yang dinilai cukup lambat dalam memproses pesanan, kekeliruan dalam pengiriman, ketersediaan barang yang minim, dan produk yang terkadang mudah rusak. Hal diindikasikan dengan hasil evaluasi setiap bulannya pada tahun 2017 penjualan toko Niaga Wood digambarkan pada grafik yang telihat bahwa telah terjadi penurunan penjualan.

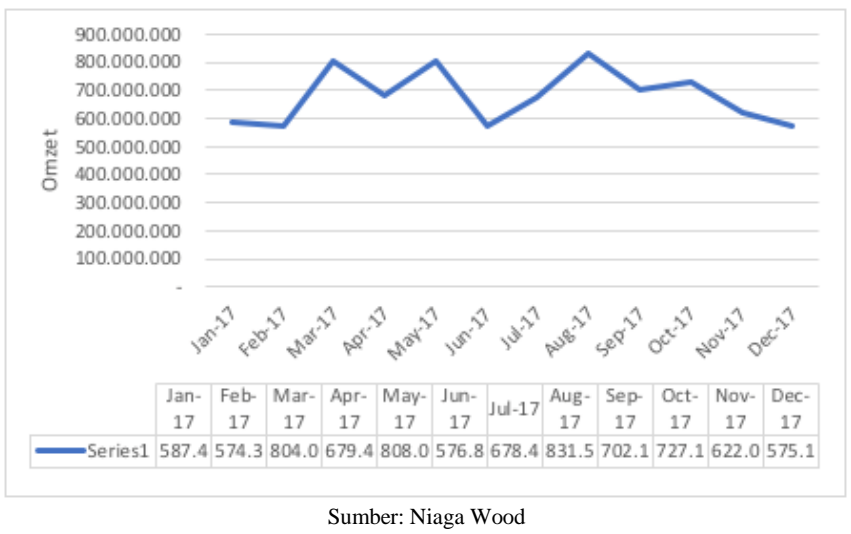

Gambar 1. Omzet Toko Niaga Wood Tahun 2017

Penurunan penjualan terus terjadi dimulai pada bulan Oktober-Desember 2017 dimana penjualan pada bulan Oktober-November mengalami penurunan penjualan sebesar Rp 105.100.000 sedangkan pada bulan november-desember kembali mengalami penurunan penjualan sebesar Rp 47.000.000. Jika dihitung penurunan penjualan yang terjadi selama oktober hingga desember mencapai Rp 152.100.000 atau penurunan penjualan yang terjadi sebesar 20,0\% (Rp. 152.100.000 / Rp 727.100.000 x 100\%). Rockefeller Foundation (dalam Griffin: 2003) telah melakukan studi tentang pelanggan yang hilang, faktor penyebabnya bisa dikarenakan oleh empat hal, yaitu karena adanya keluhan yang tidak ditangani (14\%), andanya pesaing (9\%), terjadi relokasi $(9 \%)$, dan tidak ada alasan khusus (68\%). "tidak ada alasan khusus" biasanya para pelanggan ini keluar karena diabaikan. Sebagaimana yang sudah diteliti Rockefeller Foundation, penyebab hilangnnya pelanggan yang diindikasikan tersebut dialami oleh toko Niaga Wood pada tahun 2017 mengenai keluhan pelanggan. Pengembalian barang terendah ada pada bulan januari sebesar $0,76 \%$ sedangkan tingkat retur barang tertinggi terjadi pada bulan desember sebesar 3,13\%. Penyebab terjadinya pengembalian/retur barang ini pada toko Niaga Wood bisa disebabkan karena kekeliruan pelanggan saat membeli, barang rusak saat sampai 
tujuan atau barang tertukar dengan pesanan pelanggan lain. Indikasi permasalahan tersebut tentunya mengarah pada permasalah atas keluhan pelanggan. Oleh karena itu, harus diteliti apakah pelayan toko Niaga Wood memberikan pelayanan terbaik atas setiap keluhan pelanggan yang terjadi.

Tabel 1. Tingkat Pengembalian/Retur Barang

\begin{tabular}{|c|c|}
\hline Bulan & Tingkat Pengembalian (\%) \\
\hline Jan-17 & 0.76 \\
\hline Sep-17 & 1.89 \\
\hline Aug-17 & 2.00 \\
\hline Mar-17 & 2.01 \\
\hline Feb-17 & 2.11 \\
\hline May-17 & 2.19 \\
\hline Jul-17 & 2.37 \\
\hline Oct-17 & 2.48 \\
\hline Nov-17 & 2.57 \\
\hline Jun-17 & 2.86 \\
\hline Apr-17 & 3.09 \\
\hline Dec-17 & 3.13 \\
\hline
\end{tabular}

Selain itu, kendala yang menyebabkan hilangnya pelanggan juga dapat disebabkan oleh pesaing, hal ini dialami pada tahun 2015 di mana terdapat satu pesaing baru yang menjual material dan alatalat meubel di Kota Cimahi, kemudian pada tahun 2016 hingga tahun 2018 bertambah dua toko baru dengan menjual barang yang sejenis yaitu material dan alat-alat meubel, tepatnya berlokasi di Jl. Haji Gofur, Jl. Tanimulya, Jl. Kaum.

Keterkaitan antara pelayanan dengan hilangnya pelanggan harus menjadi perhatian khususnya bagi perusahaan untuk menjaga kualitas pelayanan supaya bisa mempertahankan seluruh pelanggannya. Ketika perusahaan dianggap telah gagal memberikan kualitas pelayanan prima, hal ini akan menimbulkan suatu permasalahan, seperti pada saat pelanggan tidak dijadikan prioritas utama dikarenakan ketidakmampuan pelayan dalam mengidentifikasi pelanggan, mengidentifikasi keinginan, kebutuhan dan harapan pelanggan, serta ketidakmampuan pelayan untuk memenuhi keinginan pelanggan (Rusydi: 2017).

Berbagai macam kemungkinan penyebab terjadinya penurunan penjualan bisa terjadi, oleh karena itu perlu dilakukan penelitian untuk mengetahui mengapa permasalahan tersebut timbul. Melihat grafik diatas yang menunjukkan bahwa penurunan tidak hanya terjadi pada jumlah omzet saja, melaikan penurunan juga terjadi pada transaksi penjualan di toko Niaga Wood. Penurunan jumlah transaksi ini dapat diakibatkan karena ketidakpuasan pelanggan dalam menerima pelayanan dari perusahaan. Tujuan dari penelitian ini yakni untuk mengetahui apakah kualitas pelayanan memengaruhi loyalitas pelanggan toko B2B Niaga Wood sehingga mempengaruhi pada penjualan perusahaan tersebut.

\section{Kajian Literatur}

\subsection{Loyalitas Pelanggan}

B2B yang diterapkan perusahaan kerap kali dikaitkan dengan pentingnya membangun loyalitas pelanggan. Perusahaan yang memiliki strategi B2B merupakan perusahaan yang menawarkan produknya berupa barang dan atau jasa. Penjual sering berhadapan dengan pembeli yang telah mengenal barang yang akan dibeli dengan baik, sangat profesional dalam mengevaluasi tawarantawaran yang kompetitif. Pembeli bisnis membeli barang agar bisa membuat barang baru atau menjualnya lagi untuk medapatkan laba.

Setiap pembeli bisnis dapat dikatakan mereka cukup selektif dalam membeli produk yang dicari, ketika mereka menemukan perusahaan terpercaya yang mampu memenuhi kebutuhannya, ini akan menjadi poin penting bagi perusahaan karena pembeli bisnis memiliki kemampuan membeli dalam kuantiti yang besar dan cenderung akan terus bekerjasama atau loyal dengan perusahaan yang bergerak pada pasar B2B. 
Loyalitas menjelaskan tentang suatu kondisi yang terjadi pada satu waktu dan mensyaratkan bahwa kegiatan pembelian yang tidak terjadi hanya satu atau hanya dua kali saja, melaikan adanya pembelian secara berulang lebih dari dua kali. Secara sederhana loyalitas dapat didefinisikan sebagai perilaku membeli (purchasing behaviour). Pelanggan yang loyal tercermin melalui perilaku-perilaku di bawah ini (Griffin, 2003: 31):

a. Melakukan pembelian berulang secara teratur

b. Membeli antarlini produk dan jasa

c. Mereferensikan kepada orang lain

d. Menunjukkan kekebalan terhadap tarikan dari pesaing

Loyalitas yang dimiliki konsumen bukan bersifat statis namun dinamis, karena tingkat kualitas bisa mengalami fluktuasi yaitu mengalami kenaikan atau penurunan. Faktor terpenting dalam menentukan loyalitas konsumen adalah kualitas layanan sehingga bagi setiap bisnis harus memperhatikan dan meningkatkan segi kualitas layanannya (Laemonta dan Padmalia: 2016).

\subsection{Kualitas Pelayanan}

Kualitas pelayanan atau yang dikenal juga sebagai service quality didefinisikan sebagai "konsepsi yang abstrak dan sulit diartikan secara implisit, disebabkan oleh adanya kualitas pelayanan yang mempunyai karakteristik tidak berwujud (intangiability), bervariasi (variability), tidak tahan lama (perishability), serta dalam memproduksi dan mengkonsumsi jasa dapat terjadi secara bersamaan (inseparitibility)" (Parasaruman et al. 1988, dalam Prandita dan Iriani, 2013: 579).

Groocock (dalam O'Hara dan Frodey: 2016) juga menguraikan bahwa dari semua konsep dalam fungsi kualitas awalnya dikenal sebagai "fitness for use" oleh beberapa ahli. Seperti melihat kebutuhan akan suatu hal, maka yang diukur adalah seberapa jauh produk dapat berhasil memberikan sepenuhnya atas kebutuhan pengguna atau yang disebut "fitness for use". Konsep "fitness for use" lebih dikenal dengan sebutan "kualitas" ini adalah konsep yang cukup universal dan berlaku untuk semua barang dan jasa.

Penelitian dilakukan berada di sebuah perusahaan yang bergerak pada B2B, oleh karena itu perlu juga diketahui apa saja yang diperlukan untuk memenuhi kebutuhan pelanggan-pelanggan di mana pelanggan tersebut merupakan pemilik home industry meubel di Kota Cimahi. O'Hara dan Frodey (2016) mengatakan bahwa definisi kualitas yang digunakan dalam sektor manufaktur cenderung berfokus pada produk, menunjukkan bahwa "fitness for use" adalah kriteria utama. Meskipun dalam pekerjaan yang sama mereka juga memperingatkan bahwa, karena persepsi pelanggan kualitas dapat berubah seiring waktu berlalu, sikap pemasok pada kualitas juga harus bisa menyesuaikan untuk berubah.

Adapun dimensi pokok pada konteks kualitas pelayanan dijelaskan oleh Garvin (1987) di mana terdapat delapan dimensi pokok yang umumnya digunakan untuk mengukur kualitas pelayanan pada perusahaan barang yaitu:

1) Kinerja (performance) yaitu tentang gambaran dasar pada suatu produk. Seperti adanya ketepatan pengiriman, ketajaman gambar dan warna sebuah TV, kemudahan akses dan kenyamanan pelayanan, kebersihan masakan di restoran

2) Ciri-ciri atau keistimewaan tambahan (features), yaitu keistimewaan yang diberikan sebagai pelengkap. Seperti rumah dilengkapi dengan interior dan eksterior

3) Kehandalan (reliability), menjadikan salah satu tolak ukur untuk mengetahui seberapa besar suatu produk mengalami kerusakan atau cacat, ketika produk menunjukkan tingkat kerusakan yang semakin rendah maka hal ini menunjukkan semakin andal produk tersebut

4) Kesesuaian dengan spesifikasi (conformance to specifications), mengukur seberapa tepat dan akurat karakteristik desain memenuhi syarat yang telah distandarisasi sebelumnya. Contoh Seorang pelanggan membeli suatu produk atau jasa, harus dipastikan bahwa pelanggan tersebut menerima produk berdasarkan permintaannya mulai dari jenis produk yang diminta, adanya kesepakatan atas produk atau jasa yang dibeli hingga ketepatan waktu pengiriman.

5) Daya tahan (durability), berhubungan dengan jangka waktu lamanya produk digunakan. Bertambahnya frekuensi pemakaian memungkinkan semakin lemahnya suatu produk, namun jika seiring waktu produk digunakan sudah berada diatas pemakaian normal dan produk tetap 
berfungsi dengan baik maka produk yang bersangkutan semakin memiliki nilai lebih atas daya tahannya.

6) Serviceability, terdiri dari cepatnya pelayanan yang diberikan, kompetensi yang dimiliki setiap pelayan, kenyamanan yang diberikan kepada pelanggan, produk yang mudah direparasi, serta kopetensi juga mengaitkan tentang keramahtamahan setuiap pelayan.

7) Estetika (Aesthetic), merupakan daya pikat produk pada panca indera (rasa, aroma, suara dst), misalnya sebuat motor memiliki body bagus.

8) Kualitas yang dipersepsikan (perceived quality), yaitu gambaran mengenai reputasi penjual atas kualitas yang diberikan. Sebagai contoh merek yang lebih dikenal.

Ketika suatu bisnis yang memiliki target pasar di mana pelanggan yang dituju adalah yang bergerak dalam bidang home industry manufaktur, secara khusus bisnis tersebut harus bisa memperhatikan di mana terdapat suatu fenomena yang lebih luas lagi, mereka harus mampu bersaing tidak hanya memberikan produk saja, melaikan bisnis yang bisa memberikan layanan yang baik dan menjadi produk yang utama di pada target pasar mereka. Berfokus pada produk, setiap perusahaan dapat menggunakan layanan untuk membedakan diri dari pesaing, mengembangkan dan mengintensifkan hubungan pelanggan, meningkatkan kepuasan pelanggan, mendorong biaya pelanggan switching, dan membangun loyalitas pelanggan dari waktu ke waktu, yang dapat membantu mereka mewujudkan margin yang lebih tinggi dan pada akhirnya meningkatkan kinerja mereka melalui perluasan pendapatan (Gebauer dan Fleisch, 2007; Oliva dan Kallenberg, 2003; Raddats dan Easingwood, 2010 dalam Brown dkk: 2011).
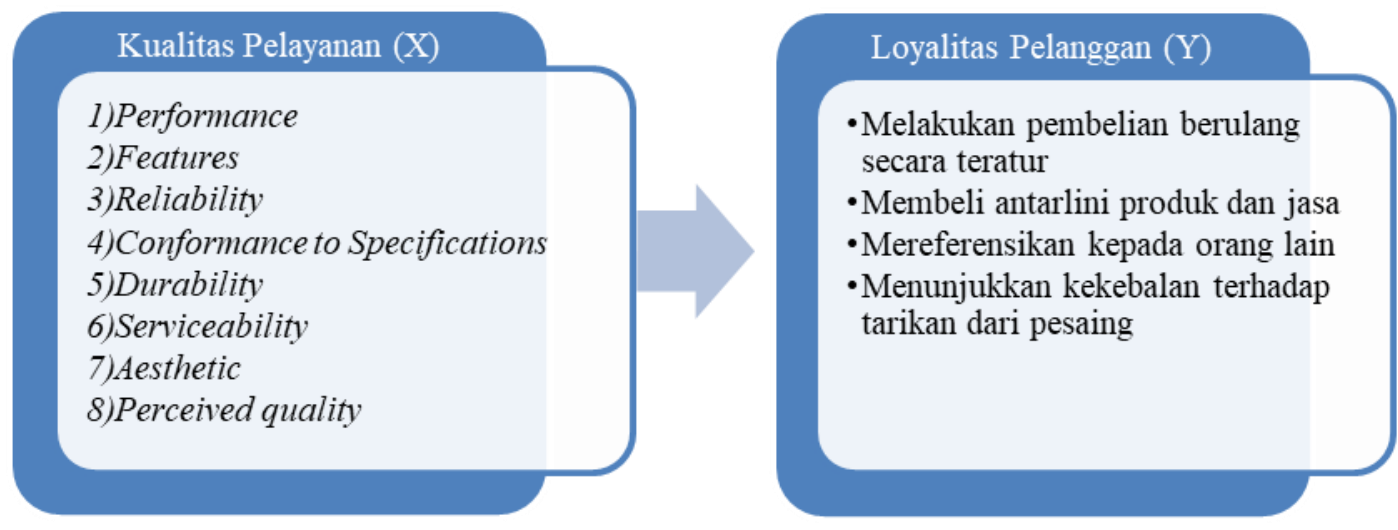

Gambar 2. Kerangka Pemikiran

Mengacu pada tujuan awal penelitian, dari hasil rumusan masalah dan kerangka pemikiran yang telah dibuat, hipotesis yang diambil peneliti adalah sebagai berikut:

H0 : Tidak terdapat pengaruh yang signifikan antara pengaruh kualitas pelayanan terhadap loyalitas pelanggan pada bisnis B2B.

H1 : Terdapat pengaruh yang signifikan antara mengetahui pengaruh kualitas pelayanan terhadap loyalitas pelanggan pada bisnis B2B.

\section{Metode Penelitian}

Penelitian ini menerapkan prosedur berdasarkan perencanaan, agar penelitian yang dilakukan dapat berjalan secara sistematis. Metode yang dilakukan dalam penelitian dimulai dari gambaran umum mengenai alur penelitian, perancangan penelitian, hingga teknik yang digunakan dalam melakukan pengolahan dan analisis data. Perancangan penelitian meliputi perancangan populasi dan sampel, model, variabel dan indikator, serta teknik pengumpulan data penelitian.

Pengolahan data adalah suatu proses dalam memeroleh data ringkasan atau angka ringkasan dengan menggunakan cara-cara atau rumus-rumus tertentu. Teknik analisa data yang digunakan penulis ini yakni dengan menggunakan teknik kuantitatif yang digunakan untuk menguji pengaruh kualitas pelayanan/service quality (X) terhadap loyalitas pelanggan/customer loyalty (Y). pada teknik analisis ini akan digunakan analisis statistik deskriptif, uji asumsi klasik, analisis korelasi, analisis 
regresi, uji hipotesis, dan analisis koefisien determinasi. Teknik pengolahan data dalam penelitian ini menggunakan penghitungan komputerisasi program SPSS 20.0.

\section{Hasil dan Pembahasan}

\subsection{Analisis Deskriptif Identitas Responden}

Analisis terhadap rata-rata perolehan omzet responden per bulan menjadi penting untuk dianilisis karena perbedaan rata-rata perolehan omzet setiap bulannya dapat mempengaruhi tingkat pembelian alat-alat meubel, perkakas dan material meubel.

Tabel 2. Deskripsi Rata-Rata Omzet Responden Per Bulan

\begin{tabular}{|c|c|c|}
\hline Rata-Rata Omzet/Bulan (Rp) & $\mathrm{F}$ & Persentase \\
\hline$<50.000 .000$ & 63 & $53,80 \%$ \\
\hline $50.000 .000-100.000 .000$ & 45 & $38,50 \%$ \\
\hline $100.000 .000-200.000 .000$ & 9 & $7,70 \%$ \\
\hline$>200.000 .000$ & 0 & $0,00 \%$ \\
\hline Total & 117 & $100,00 \%$ \\
\hline
\end{tabular}

Tabel 3. Deskripsi Usia Bisnis Meubel Responden

\begin{tabular}{|c|c|c|}
\hline Usia Bisnis & $\mathrm{F}$ & Persentase \\
\hline$<2$ Tahun & 10 & $8,50 \%$ \\
\hline $2-5$ Tahun & 39 & $33,30 \%$ \\
\hline 5-10 Tahun & 35 & $29,9 \%$ \\
\hline$>10$ Tahun & 33 & $28,20 \%$ \\
\hline Total & 117 & $100,00 \%$ \\
\hline
\end{tabular}

Pada tabel 2 di atas jumlah responden terbanyak adalah yang memperoleh rata-rata omzet per bulan $<50.000 .000$ dengan nilai persentase $53,80 \%$ dan terdiri dari 63 responden. Data demografi yang diperoleh berdasarkan hasil kuisioner mengenai usia bisnis responden memperlihatkan responden dari pelanggan toko Niaga Wood. Sementara tabel 3 menunjukkan jumlah terbanyak yang menjadi responden penelitian ini ada pada kelompok usia bisnis di antara usia bisnis meubel yang telah di jalankan rentan 2-5 tahun sebanyak 39 orang dengan nilai persentase 33,30\%.

\subsection{Validitas dan Reliabitas}

Validitas dilakukan dengan menggunakan metode analisis korelasi. Perhitungan dilakukan dengan bantuan program SPSS. Hasil dari perhitungan korelasi product moment pada tabel hasil validitas dapat diketahui bahwa semua item pertanyaan dari variabel kualitas pelayana dan loyalitas pelanggan dinyatakan valid karena diperoleh hasil yang signifikan di mana $r$ hitung $>r$ tabel, dengan jumlah responden $n=117$ dan taraf signifikansi $(\alpha)=0,05$.

Tabel 4. Validitas Kualitas Pelayanan

\begin{tabular}{|c|c|c|c|}
\hline No Item & r hitung & $\mathrm{r}$ tabel & Keterangan \\
\hline $\mathrm{X} 1$ & 0,653 & 0,180 & Valid \\
\hline $\mathrm{X} 2$ & 0,682 & 0,180 & Valid \\
\hline $\mathrm{X} 3$ & 0,474 & 0,180 & Valid \\
\hline $\mathrm{X} 4$ & 0,502 & 0,180 & Valid \\
\hline $\mathrm{X} 5$ & 0,506 & 0,180 & Valid \\
\hline $\mathrm{X} 6$ & 0,349 & 0,180 & Valid \\
\hline $\mathrm{X} 7$ & 0,555 & 0,180 & Valid \\
\hline $\mathrm{X} 8$ & 0,601 & 0,180 & Valid \\
\hline $\mathrm{X} 9$ & 0,450 & 0,180 & Valid \\
\hline $\mathrm{X} 10$ & 0,521 & 0,180 & Valid \\
\hline
\end{tabular}




\begin{tabular}{|l|l|l|l|}
\hline $\mathrm{X} 11$ & 0,608 & 0,180 & Valid \\
\hline $\mathrm{X} 12$ & 0,636 & 0,180 & Valid \\
\hline $\mathrm{X} 13$ & 0,269 & 0,180 & Valid \\
\hline $\mathrm{X} 14$ & 0,723 & 0,180 & Valid \\
\hline $\mathrm{X} 15$ & 0,730 & 0,180 & Valid \\
\hline $\mathrm{X} 16$ & 0,683 & 0,180 & Valid \\
\hline $\mathrm{X} 17$ & 0,692 & 0,180 & Valid \\
\hline $\mathrm{X} 18$ & 0,695 & 0,180 & Valid \\
\hline $\mathrm{X} 19$ & 0,585 & 0,180 & Valid \\
\hline $\mathrm{X} 20$ & 0,589 & 0,180 & Valid \\
\hline
\end{tabular}

Tabel 5. Validitas Loyalitas Pelanggan

\begin{tabular}{|c|c|c|c|}
\hline No Item & r hitung & r tabel & Keterangan \\
\hline Y1 & 0,464 & 0,180 & Valid \\
\hline Y2 & 0,403 & 0,180 & Valid \\
\hline Y3 & 0,484 & 0,180 & Valid \\
\hline Y4 & 0,443 & 0,180 & Valid \\
\hline Y5 & 0,478 & 0,180 & Valid \\
\hline \multicolumn{5}{|c}{ Sumber: Hasil Olah Data SPSS (2018) } \\
\hline
\end{tabular}

Tabel 6. Reliabilitas Kualitas Pelayanan Terhadap Loyalitas Pelanggan

\begin{tabular}{|c|c|c|}
\hline Cronbach's Alpha & Cronbach's Alpha Based on Standardized Items & N of Items \\
\hline 0,743 & 0,917 & 26 \\
\hline
\end{tabular}

Hasil reliabilitas pada varibel penelitian ini adalah 0,743 yang artinya reliabilitas dapat diterima, dimana nilai Cronbach's Alpha $\geq 0,60$ oleh karena itu semua variabel yang dijadikan dalam penelitian dapat digunakan sebagai alat ukur yang dapat diandalkan atau dipercaya.

\subsection{Analisis Deskriptif}

Tabel 7 berisi statistik deskriptif yang menunjukkan mean dari kualitas pelayanan dan menggambarkan data yang telah terkumpul. Dari delapan dimensi dapat dilihat bahwa mean terendah di tunjukkan dari dimensi durability (daya tahan) dengan nilai mean 3,80 dengan skor terendah dua (2) dan skor tertinggi (5), walaupun dimensi ini termasuk ke dalam dimensi yang memiliki nilai rendah, namun jika digolongkan kedalam interpretasi hasil analisis deskriptif durability (daya tahan) dikelompokkan ke dalam kriteria dengan interval 3,40 - 4,19 dengan hasil interpretasi baik/tinggi. Standar deviasi dari dimensi durability (daya tahan) sebesar 22,8\% (0,865/3,80x100\%), dengan persentase tersebut sebagaimana yang dikemukakan Santosa (2012) bahwa standar deviasi lebih dari $20 \%$ dari mean menunjukkan adanya variasi jawaban yang semakin heterogen atau cukup beragam. Disamping itu, mean tertinggi dalam variabel Kulalitas Pelayanan ada pada dimensi conformance to specifications (kesesuaian dengan spesifikasi) yang memiliki nilai mean 4,50 dengan skor terendah dua (2) dan skor tertinggi (5). Jika dikelompokkan dalam interpretasi hasil analisis deskriptif nilai mean tersebut ada pada interval 4,20 - 5,00 yang menginterpretasikan bahwa dimensi conformance to specifications (kesesuaian dengan spesifikasi) adalah sangat baik/sangat tinggi. standar deviasi dari dimensi conformance to specifications sebesar 13,4\% (0,602/4,50x 100\%), dengan persentase tersebut sebagaimana yang dikemukakan Santosa (2012) bahwa standar deviasi kurang dari 20\% dari mean menunjukkan adanya variasi jawaban yang semakin homogen atau variasi jawaban yang kecil.

Nilai mean kualitas pelayanan dalam penelitian adalah 4,15 dengan skor terendah dua (2) dan skor tertinggi (5), jika dikelompokan kedalam interpretasi nilai hasil analisis deskriptif maka nilai mean tersebut berada pada kriteria dengan interval 3,40 - 4,19 yang menunjukkan bahwa hasil interpretasi dari variabel kualitas pelayanan baik/tinggi. Standar deviasi dari kualitas pelayanan sebesar 16,8\% $(0,700 / 4,15 \times 100 \%)$, dengan persentase tersebut sebagaimana yang dikemukakan Santosa (2012) 
bahwa standar deviasi kurang dari 20\% dari mean menunjukkan adanya variasi jawaban yang semakin homogen atau variasi jawaban yang kecil.

Tabel 7. Statistik Deskriptif Kualitas Pelayanan terhadap Loyalitas Pelanggan

\begin{tabular}{|l|c|c|c|c|c|}
\hline & $\mathrm{N}$ & Min & Max & Mean & Std. Dev \\
\hline Performance & 117 & 3 & 5 & 4,21 & 0,633 \\
\hline Features & 117 & 2 & 5 & 3,92 & 0,770 \\
\hline Reliability & 117 & 2 & 5 & 4,32 & 0,721 \\
\hline Conformance to Specifications & 117 & 2 & 5 & 4,50 & 0,602 \\
\hline Durability & 117 & 2 & 5 & 3,80 & 0,865 \\
\hline Serviceability & 117 & 3 & 5 & 4,14 & 0,617 \\
\hline Aesthetic & 117 & 2 & 5 & 4,22 & 0,750 \\
\hline Perceived Quality & 117 & 3 & 5 & 4,09 & 0,647 \\
\hline Service Quality & 117 & 2 & 5 & 4,15 & 0,700 \\
\hline
\end{tabular}

Tabel 8. Statistik Deskriptif Dimensi Loyalitas Pelanggan

\begin{tabular}{|c|c|c|c|c|c|}
\hline & $\mathrm{N}$ & Min & Max & Mean & Std. Dev \\
\hline $\mathrm{Y} 1$ & 117 & 3 & 5 & 4,59 & 0,528 \\
\hline $\mathrm{Y} 2$ & 117 & 4 & 5 & 4,68 & 0,467 \\
\hline Y3 & 117 & 3 & 5 & 4,54 & 0,609 \\
\hline $\mathrm{Y} 4$ & 117 & 3 & 5 & 4,56 & 0,532 \\
\hline Y5 & 117 & 2 & 5 & 4,07 & 0,716 \\
\hline Loyalitas Pelanggan & 117 & 2 & 5 & 4,48 & 0,570 \\
\hline
\end{tabular}

Tabel 8 yaitu statistik deskriptif variabel loyalitas pelanggan yang terdiri dari lima (5) indikator, rata-rata skor terendah dua (2) dan skor tertinggi lima (5) dengan nilai mean 4,48, jika dikelompokkan dalam interval maka loyalitas pelanggan ada di antara 4,20 - 5,00 yang menginterpretasikan bahwa dimensi sangat baik/sangat tinggi. Hasil mean terendah pada indikator tersebut ada pada indikator Y5 (pembelian berulang karena pengiriman cepat dan gratis) yaitu 4,07, sedangkan mean tertinggi ada pada indikator Y2 (harga produk bersaing) yaitu 4,68. Standar deviasi dari loyalitas pelanggan sebesar $12,7 \%(0,570 / 4,48 \times 100 \%)$, Persentase kurang dari $20 \%$ dari mean tersebut menunjukkan adanya variasi jawaban yang semakin homogen atau variasi jawaban yang kecil.

\subsection{Analisis Korelasi dan Regresi}

Output pada tabel 9 menjelaskan antara Kualitas Pelayanan (X) dengan Loyalitas Pelanggan (Y) memiliki nilai signifikansi $0,000<0,05$ yang berati terdapat korelasi yang signifikan. Mengenai tingkat hubungan pada masing-masing variabel tergambar melalui nilai Pearson Correlation yaitu 0,739 , hal ini menginterpretasikan nilai koefisien korelasi dengan interval 0,60 - 0,79 yang memiliki arti bahwa terdapat hubungan positif yang kuat antara variabel.

Tabel 9. Korelasi

\begin{tabular}{|ll|c|c|}
\hline \multirow{2}{*}{ Pearson Correlation } & Loyalitas Pelanggan & Kualitas Pelayanan \\
\hline & Loyalitas Pelanggan & 1,000 & 0,739 \\
\cline { 2 - 4 } & Kualitas Pelayanan & 0,739 & 1,000 \\
\hline \multirow{2}{*}{ Sig. (1-tailed) } & Loyalitas Pelanggan & 0,000 & 0,000 \\
\cline { 2 - 4 } & Kualitas Pelayanan & 0,000 & 0,000 \\
\hline & Loyalitas Pelanggan & 117 & 117 \\
\cline { 2 - 4 } & Kualitas Pelayanan & 117 & 117 \\
\hline
\end{tabular}

Tabel 10. Model Summary

\begin{tabular}{|c|c|c|c|c|}
\hline Model & $\mathrm{R}$ & $\mathrm{R}$ Square & Adjusted R Square & Std. Error of the Estimate \\
\hline 1 & $0,739^{\mathrm{a}}$ & 0,546 & 0,542 & 1,086 \\
\hline \multicolumn{5}{|c}{ Sumber: Hasil Olah Data SPSS (2018) } \\
\hline
\end{tabular}


Tabel 11. Coefficients

\begin{tabular}{|c|c|c|c|c|c|c|c|}
\hline \multirow[t]{2}{*}{ Model } & \multicolumn{2}{|c|}{$\begin{array}{l}\text { Unstandardized } \\
\text { Coefficients }\end{array}$} & \multirow{2}{*}{$\frac{\text { Std Coef }}{\text { Beta }}$} & \multirow[t]{2}{*}{$\mathrm{t}$} & \multirow[t]{2}{*}{ Sig. } & \multicolumn{2}{|c|}{$\begin{array}{l}\text { Collinearity } \\
\text { Statistics }\end{array}$} \\
\hline & B & Std. Error & & & & Tolerance & VIF \\
\hline \begin{tabular}{l|l|}
1 & Constant
\end{tabular} & 9,871 & 1,073 & & 9,203 & 0,000 & & \\
\hline Kualitas Pelayanan & 0,151 & ,013 & 0,739 & 11,766 & 0,000 & 1,000 & 1,000 \\
\hline
\end{tabular}

Tabel 10 menjelaskan besarnya nilai korelasi hubungan (R) yaitu sebesar 0,739. Selain itu tabel ini juga memperlihatkan output dari variabel bebas (Kualitas Pelayanan) dan variabel terikat (Loyalitas Pelanggan) diperoleh koefisiensi determinasi (R2) sebesar 0,546, yang mengandung pengertian bahwa pengaruh variabel bebas (kualitas pelayanan) terhadap variabel terikat (loyalitas pelanggan) adalah sebesar 54,6\%, sedangkan sisanya 45,4\% dipengaruhi oleh variabel lain.

Pada tabel 11, kolom B menunjukkan Constant $=9,865$, sedangkan nilai Kualitas Pelayanan adalah 0,151 sehingga persamaan regresinya:

$$
\mathrm{Y}=\mathrm{a}+\mathrm{b} . \mathrm{X} \text { atau } \mathrm{Y}=9,871+0,151 \mathrm{X}
$$

Output di atas diketahui nilai $\mathrm{t}=9,203$ dengan nilai signifikansi $0,000<0,05$, maka H0 ditolak dan H1 diterima, artinya terdapat pengaruh nyata (signifikan) antara variabel Kualitas Pelayanan (X) terhadap variabel Loyalitas Pelanggan (Y).

\subsection{Uji Hipotesis}

Nilai F dalam analisis pada table 12 adalah 138,437. Angka ini adalah nilai F hitung, yang selanjutnya dibandingkan dengan nilai $\mathrm{F}$ table di mana $\mathrm{F}$ table untuk 117 responden dengan taraf signifikansi 5\% atau persentase distribusi $\mathrm{F}$ untuk probabilitas $=0,05$.

df (n1) = k-1 jadi 2-1 = 1

df $(\mathrm{n} 2)=\mathrm{n}-\mathrm{k}-1$ jadi $117-1-1=115$

Maka nilai untuk df (n1) adalah 1 dan nilai df (n2) adalah 115, maka nilai F pada tabel distribusi $\mathrm{F}$ pada penelitian ini adalah 3,92 .

$\mathrm{F} 0 \geq \mathrm{Ft}$, dengan taraf signifikansi $5 \%$

$$
138,437 \geq 3,92
$$

Tabel 12. Model Summary

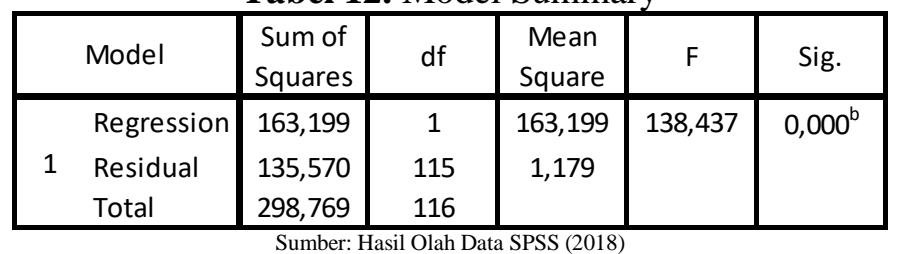

\begin{tabular}{|c|c|c|c|c|c|c|c|}
\hline \multirow[t]{2}{*}{ Model } & \multicolumn{2}{|c|}{$\begin{array}{l}\text { Unstandardized } \\
\text { Coefficients }\end{array}$} & \multirow{2}{*}{$\begin{array}{c}\text { Std. Coef } \\
\text { Beta }\end{array}$} & \multirow[t]{2}{*}{$\mathrm{t}$} & \multirow[t]{2}{*}{ Sig. } & \multicolumn{2}{|c|}{$\begin{array}{c}\text { Collinearity } \\
\text { Statistics }\end{array}$} \\
\hline & $\mathrm{B}$ & Std. Error & & & & Tolerance & VIF \\
\hline 1 (Constant) & 9,871 & 1,073 & & 9,203 & 0,000 & & \\
\hline $\begin{array}{l}\text { Kualitas } \\
\text { Pelayanan }\end{array}$ & 0,151 & 0,013 & 0,739 & 11,766 & 0,000 & 1,000 & 1,000 \\
\hline
\end{tabular}

Tabel 13. Coefficients

Nilai t menunjukkan 9,203 untuk Kualitas Pelayanan (X). di mana nilai t hitung kedua variabel tersebut lebih besar dari t tabel (taraf signifikansi 5\% dan jumlah responden 117) maka disimpulkan bahwa terdapat pengaruh yang signifikan antara Kualitas Pelayanan (X) terhadap Loyalitas Pelanggan (Y).

$\mathrm{t}$ tabel $>\mathrm{t}$ hitung, dan probabilitas signifikan $<0,059,203>1,657$ 
Tabel 14. Model Summary

\begin{tabular}{|l|c|c|r|r|}
\hline Model & $\mathrm{R}$ & R Square & Adjusted R Square & Std. Error of the Estimate \\
\hline 1 & $0,739^{\mathrm{a}}$ & 0,546 & 0,542 & 1,086 \\
\hline
\end{tabular}

Koefisien determinasi (R2) pada penelitian ini adalah antara $0(0 \%)<\mathrm{R} 2<1(100 \%)$, di mana output pada Tabel 4.23 Model Summary menunjukkan nilai koefisien determinasi (R Square) sebesar 0,739 (Nilai 0,739 adalah kuadrat dari koefisien determinasi). R Square 0,546 sama dengan 54,6\%. Angka tersebut menjelaskan bahwa Kualitas Pelayanan berpengaruh terhadap Loyalitas Pelanggan sebesar 54,6\%. Sedangkan sisanya 45.4\% (100\% - 54,6\%) dipengaruhi oleh variabel lain.

\section{Kesimpulan}

Kesimpulan yang dapat diambil dari hasil penelitian dengan mengumpulkan data merupakan akhir dari kumpulan ide atau gagasan atas pembahasan dan penelitian yang telah dilakukan. Berikut merupakan kesimpulan dari penelitian di atas:

1. Kualitas pelayanan pada bisnis B2B toko Niaga Wood dari hasil analisis menunjukkan bahwa pelanggan toko Niaga Wood sudah mendapatkan pelayanan baik dari toko Niaga Wood. Dari dimensi yang diambil dalam penelitian terdiri dari delapan dimensi, di antaranya adalah dimensi performance (kinerja), features (keistimewaan), reliability (keandalan), conformance to specifications (kesesuaian dengan spesifikasi), durability (daya tahan), serviceability (kemampuan melayani), aesthetic (estetika), dan perceived quality (kualitas yang dipersepsikan). Dari kedelapan dimensi tersebut penilaian terendah pada penelitian ini ada pada dimensi Durability (daya tahan). Disisi lain, terdapat beberapa indikator yang dapat ditingkatkan dari dimensi serviceability (kemampuan melayani), dan perceived quality (kualitas yang dipersepsikan). Disamping itu, dimensi Conformance to Specifications (kesesuaian dengan spesifikasi) mendapatkan penilaian nilai tertinggi.

2. Loyalitas pelanggan toko Niaga Wood dari hasil penelitian dinilai sangat baik. Penilaian yang diberikan pelanggan toko Niaga Wood terendah ada pada pertanyaan "fasilitas jasa pengiriman cepat dan gratis membuat Anda ingin membeli produk ke toko Niaga Wood". Sedangkan, nilai tertinggi ada pada pertanyaan "harga produk yang ditawarkan toko Niaga Wood dapat bersaing", hal ini yang dapat meningkatkan turn over penjualan di mana hal tersebut berbanding lurus dengan jumlah transaksi yang juga akan bertambah. Oleh karena itu, loyalitas pelanggan bisa terus meningkat dan pelanggan bisa menjadi mitra bisnis toko Niaga Wood dalam jangka waktu yang jauh lebih lama.

3. Pengaruh antara kualitas pelayanan terhadap loyalitas pelanggan pada bisnis B2B toko Niaga Wood memiliki pengaruh positif. Hasil uji hipotesis dari uji statistik " $t$ " diketahui bahwa t tabel lebih kecil dibandingkan $t$ hitung dan probabilitas dinyatakan signifikan di mana hal tersebut membuktikan adanya pengaruh yang signifikan dan positif terhadap Kepuasan Pelanggan juga Loyalitas Pelanggan. Loyalitas pelanggan akan tetap memiliki nilai 9,871 saat Kualitas Pelayanan nilainya nol, adapun jika terjadi peningkatan Kualitas Pelayanan yang dirasakan pelanggan sebesar satu satuan maka akan berbanding lurus dengan peningkatan Loyalitas Pelanggan toko Niaga Wood sebesar 0,151 satuan. Besarnya pengaruh Kualitas Pelayanan terhadap Kepuasan Pelanggan toko Niaga Wood sebesar 54,6\% di mana pengaruh pelayanan memberikan peranan penting sebagai kesuksesan perusahaan, sementara sisanya dipengaruhi oleh aspek lain sebesar 45,4\% yang tidak dijelaskan pada penelitian ini.

\section{Daftar Pustaka}

Garvin, D. A. (1987). Competing on the Eight Dimensions of Quality. Harvard Business Review , 65 (6), 101-109.

Griffin, J. (2003). Customer Loyality - Menumbuhkan dan Mempertahankan Kesetiaan Pelanggan. Jakarta: Erlangga.

Rusydi, M. (2017). Customer Excellent . Yogyakarta: Gosyen Publishing.

Prandita, L., \& Iriani, S. S. (2013). Pengaruh Kulaitas Produk, Kualitas Layanan, dan pengaruh kualitas produk, kualitas layanan, danEmosional terhadap Kepuasan pelanggan Sogo Departemen Store. Jurnal Ilmu Manajemen , 1 (2), 575-590. 
O'Hara, J. C., \& Frodey, A. (2016). Service Quality Model for Manufacturing. Management Decission, 31 (8).

Tjiptono, F., \& Chandra, G. (2011). Service Quality and Satisfaction (ed 3). Yogyakarta: Andi.

Brown, B., Sichtmann, C., \& Musante, M. A Model of Product to Service Brand Extention Success Factors in B2B buying Contexts. Journal of Business \& Industrial Marketing , 26 (3), 220-210.

*Email korespondensi:

Lmarjani@rocketmail.com 